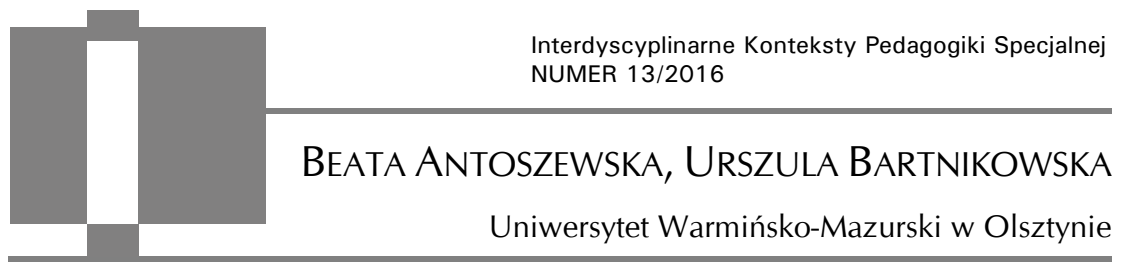

\title{
Kategorie zdrowia, choroby w kontekście niepełnosprawności - ujęcie teoretyczne
}

Od dnia narodzin każdy z nas posiada bowiem jakby dwa paszporty - przynależy zarówno do świata zdrowych, jak $i$ do świata chorych ${ }^{1}$.

To niekorzystne, kiedy człowiek dostaje to, co chce dostać. To choroba sprawia, że zdrowie jest przyjemne².

\begin{abstract}
Beata Antoszewska, Urszula Bartnikowska, Kategorie zdrowia, choroby w kontekście niepetnosprawności - ujęcie teoretyczne [Categories of health and disease in the context of disability - theoretical framework]. Interdyscyplinarne Konteksty Pedagogiki Specjalnej, nr 13, Poznań 2016. Pp. 67-86. Adam Mickiewicz University Press. ISSN 2300-391X

Life is of great value to any human being and can be considered to be a fundamental concept. It has a determined temporal dimension, although it remains unknown to a given individual. An overview of relevant literature demonstrates that much has been written on the subject of health and ability and it has been quite extensively discussed. Yet this concept remains valid because its meaning is constantly changing. People are not able to completely free themselves from diseases/disabilities. During one's lifetime one is exposed to periodic or permanent difficulties or limitations. Human life involves functioning on the border of health and disease, full

1 S. Sontag, Choroba jako metafora AIDS i jego metafory, PIW, Warszawa 1999, s. 7.

${ }^{2}$ Heraklit za: Z. J. Lipowski, Physical Illness the indyvidual and the coping process, „Psychiat. Med.” 1979, 1, s. 99-100.
\end{abstract}


ability and disability. It is important, however, how one deals with difficulties that one must face, who one will meet on one's way and what kind of help will be offered. This paper aims to present a theoretical framework of health and disease, including chronic disease and disability.

KEY WORDS: health, disease, chronic disease, disability

\section{Wprowadzenie}

Życie to dla każdego człowieka wielka wartość, fundamentalne pojęcie. Ma ono określony wymiar czasowy, jednak mu nieznany. Nieznany jest także jego bieg i jakość. Czesław Kosakowski pisze, że: „tylko z pozoru jesteśmy "panami» własnego życia"3 bowiem uwarunkowane jest ono wieloma czynnikami. Jednym $z$ nich jest zdrowie i pełna sprawność zmieniająca się w różnych fazach rozwoju człowieka.

Piśmiennictwo dowodzi, że wiele napisano i wiele dyskutowano na temat zdrowia. Jednak zagadnienie to pozostaje nadal aktualne, ponieważ jego znaczenie zmienia się z czasem, środowiskiem i sposobem życia ${ }^{4}$. Człowiek, jak i cała społeczność, powinny dążyć do uzyskania i utrzymania zdrowia ${ }^{5}$.

Zdrowie i sprawność pomaga człowiekowi osiągać dobre wyniki w nauce, pracy czy w innych obszarach jego aktywności ${ }^{6}$. Istnieje wówczas większe prawdopodobieństwo, że człowiek będzie mógł prowadzić produktywne, sensowne, twórcze i samodzielne życie 7 .

${ }^{3}$ C. Kosakowski, Węzłowe problemy pedagogiki specjalnej, Wydawnictwo Edukacyjne Akapit, Torun 2013, s. 13.

${ }^{4}$ R. Dubos, Cztowiek, środowisko, adaptacja, PZWL, Warszawa 1970.

${ }^{5}$ J. Aleksandrowicz, Sumienie ekologiczne, Biblioteka Wiedzy Współczesnej OMEGA, Warszawa 1979.

${ }^{6}$ I. Heszen-Klemens, Poznawcze uwarunkowania zachowania się wobec własnej choroby, Zakład Narodowy Imienia Ossolińskich, Wydawnictwo Polskiej Akademii Nauk, Wrocław 1979, s. 11.

${ }^{7}$ R. Ossowski, Teoretyczne i praktyczne podstawy rehabilitacji, Wydawnictwo Uczelniane Wyższej Szkoły Pedagogicznej w Bydgoszczy, Bydgoszcz 1999. 
Osoba zdrowa inaczej patrzy na życie, na swoje możliwości, pragnie patrzeć w przyszłość. Perspektywę tę zmienia choroba, niepełnosprawność, reorganizując (przynajmniej czasowo) hierarchię wartości, utrudniając lub ograniczając jego funkcjonowanie.

W ciągu życia jesteśmy narażeni na występowanie okresowych bądź trwałych utrudnień lub ograniczeń. Można rzec, że życie człowieka to funkcjonowanie na granicy zdrowia i choroby, pełnej sprawności i niesprawności. Istotne jest jednak to, w jaki sposób człowiek poradzi sobie z napotkanymi utrudnieniami, kogo spotka na swej drodze i jaka pomoc zostanie mu udzielona.

\section{Pojęcie zdrowia}

Definiowanie pojęć często implikuje trudności. Przyjęcie wąskiej perspektywy rozważań w zakresie danego pojęcia ogranicza wyjaśnienia. Z kolei perspektywa odwrotna, szeroka naraża autora na krytykę i nieścisłości. Jednak próba definiowania i wyjaśnienia używanych pojęć jest istotna. Wielu autorów podkreśla, iż w definiowaniu pojęcia zdrowia napotykamy szereg trudności ${ }^{8}$. Ewa Stawowy ${ }^{9}$ pisze, że nie są one mniejsze niż te związane $z$ określeniem celu i sensu życia. W próbach wyjaśniania - twierdzi autorka - jest wiele deklaratywności. Medycyna, podkreślając spójność somatopsychiczną, nie przenosi tego na swoje instytucje, ponieważ zachowują się one tak, jakby człowiek był wyłącznie biologiczną maszyną ${ }^{10}$.

8 Zob. M. Wilson za: Aleksandrowicz J., Sumienie ekologiczne, Biblioteka Wiedzy Współczesnej OMEGA, Warszawa 1979; G. Dolińska-Zygmunt, Teoretyczne podstawy refleksji o zdrowiu, [w:] Podstawy psychologii zdrowia, red. G. Dolińska-Zygmunt, Wydawnictwo Uniwersytetu Wrocławskiego, Wrocław 2001, s. 17; H. Kirschner, Pojęcie $z$ drowia $i$ jego ocena, [w:] Medycyna zapobiegawcza $i$ środowiskowa. Higiena - ekologia kliniczna - zdrowie, red. Z. Jethona, PZWL, Warszawa 1997; J. Aleksandrowicz, Nie ma nieuleczalnie chorych, Wydawnictwo Iskry, Warszawa 1982.

${ }_{9}$ Zob. J. Aleksandrowicz, E. Stawowy, Tyle wart jest człowiek..., Wydawnictwo Lubelskie, Lublin 1992, s. 193.

10 Problem ten dostrzegała także: I. Heszen-Klemens, Psychologia medyczna. Główne kierunki badań, Uniwersytet Śląski, Katowice 1983. 
W literaturze przedmiotu zdrowie bywa określane jako stan przeciwny chorobie, patologii, ułomności. Jednak takie ujęcie zdrowia nie prowadzi do satysfakcjonujących wyjaśnień, lecz wprost przeciwnie - zmusza do poszukiwań.

Zatem zdrowie zgodnie określane jest jako pojęcie wielowymiarowe ${ }^{11}$ czy też wieloaspektowe ${ }^{12}$, odzwierciedlające "sieć powiązań rozmaitych wymiarów i poziomów złożonego fenomenu życia"13. Poza biologią i medycyną analizuje się je na gruncie socjologii oraz psychologii, ale także i religii. Zdrowie stanowi kategorię społeczną, obyczajową i kulturową ${ }^{14}$ wzajemnie się determinującą i przenikającą ${ }^{15}$.

Rozpatrując pojęcie „zdrowia” w perspektywie biologicznej i medycznej, akcentuje się wyraźnie aspekt anatomiczny i fizjologiczny organizmu ludzkiego. Zdrowie będzie ujmowane od strony jakości procesów biologicznych organizmu człowieka ${ }^{16}$, które warunkuje jego potencjał genetyczny, wiek i płeć ${ }^{17}$. Barbara Uramowska-Żyto pisze, iż

doskonałe zdrowie może być traktowane jako stan, w którym każda komórka ciała funkcjonuje na optymalnym poziomie i $\mathrm{w}$ doskonałej

11 Np. G. Chojnacka-Szawłowska, Rozpoznanie choroby nowotworowej. Uwarunkowania psychologiczne, PZWL, Warszawa 1998, s.11.

12 I. Obuchowska, M. Krawczyński, Chore dziecko, Nasza Księgarnia, Warszawa 1991, s. 56.

13 G. Dolińska-Zygmunt, op. cit., s. 17.

$14 \mathrm{~J}$. Aleksandrowicz, Nie ma nieuleczalnie chorych, Wydawnictwo Iskry, Warszawa 1982, s. 78.

15 W. Piątkowski, Choroba jako zjawisko socjologiczne. Wprowadzenie do wybranych koncepcji badawczych, [w:] Zdrowie $i$ choroba. Wybrane problemy socjologii medycyny, red. J. Barański, W. Piątkowski, Oficyna Wydawnicza ATUT, Wrocławskie Wydawnictwo Oświatowe, Wrocław 2002.

16 S. Kornas, Nauczanie etyki czynnikiem integrujacym studia medyczne, [w:] Nauczanie etyki w uczelniach medycznych, red. J. Suchorzewska, M. Olejniczak, Akademia Medyczna w Gdańsku, Gdańsk 2007, s. 94.

17 Za: E. Kościńska, Biologiczne aspekty zdrowia, [w:] Konteksty zdrowia i edukacji zdrowotnej, red. M. Kuchcińska, E. Kościńska, Wydawnictwo Uniwersytet Kazimierza Wielkiego, Bydgoszcz 2010, s. 44. 
harmonii z każdą inną komórką lub jako stan, w którym każdy organ funkcjonuje na optymalnym poziomie $\mathrm{w}$ całkowitej harmonii $\mathrm{z}$ każdym innym organem ${ }^{18}$.

Omawiana perspektywa jest istotna aczkolwiek niewystarczająca. Elżbieta Kościńska ${ }^{19}$ wyjaśnia, że podejście biologiczne jest częściowo uzasadnione, gdy rozpatruje się je w sytuacji choroby ostrej, krótkotrwałej wymagającej podjęcia natychmiastowych działań. Aktualnie jednak obserwujemy zmiany w charakterze pojawiających się chorób. Poważny problem stanowią choroby przewlekłe, nieuleczalne, powodujące niepełnosprawność, zmianę jakości życia człowieka, co wskazuje na niewystarczalność wymiaru biologicznego i jednoczesną potrzebę szerszego spojrzenia.

Opisując zdrowie z punktu widzenia psychologii, uwypukla się jego wymiar psychiczny, podkreślając także zjawiska z nim powiązane. Przykładem tegoż rozumienia jest ujęcie J. Prokupka, który definiuje zdrowie psychiczne jako

stan, kiedy wszystkie funkcje psychiczne przebiegają $\mathrm{w}$ optymalny sposób, harmonijnie, umożliwiają prawidłowe odbieranie zewnętrznej rzeczywistości, adekwatne i szybkie reagowanie na wszystkie bodźce, a także na rozwiązywanie zarówno codziennych, jak i nieoczekiwanych zadań, stałe doskonalenie się i uzyskiwanie satysfakcji ze swoich czynności ${ }^{20}$.

Podobne ujęcie prezentuje Halina Wardaszko-Łykowska21. Autorka pisze, że osoba zdrowa psychicznie ma realistyczną wiedzę o sobie, akceptuje siebie wraz z mocnymi czy słabymi punktami, potrafi w sposób autentyczny zajmować się innymi, kierując się

18 B. Uramowska-Żyto, Zdrowie $i$ choroba w świetle wybranych teorii socjologicznych, Instytut Filozofii i Socjologii PAN, Warszawa 1992, s. 6.

19 E. Kościńska, op. cit.

20 Za: O. Kondas, Psychologia kliniczna, Państwowe Wydawnictwo Naukowe, Warszawa 1984, s. 48.

${ }^{21} \mathrm{H}$. Wardaszko-Łykowska, Wprowadzenie do zagadnień psychologii w praktyce lekarskiej [w:] Psychologia w praktyce lekarskiej, red. M.H. Hollender, PZWL, Warszawa 1975, s. 24. 
w swym postępowaniu bardziej wartościami wewnętrznymi, umie dbać o swoje sprawy, nie szkodząc innymi, znosić frustracje. Zdrowie psychiczne oznacza pozytywne nastawienie do siebie oraz innych ludzi, ale także pozytywne nastawienie do swojego życia. Postrzeganie życia jako pewnej wartości, którą jesteśmy w stanie realizować.

Socjologia natomiast koncentruje się na wymiarze społecznym, uwydatniając relacje zachodzące między człowiekiem a środowiskiem społecznym. Tu zdrowie rozpatrywane jest również jako stan „optymalnej zdolności do efektywnego wykonywania cenionych zadań" 22.

Aktualnie coraz częściej wskazane ujęcia rozszerza się o wymiar duchowy. Wchodząc w to ujęcie, należy zauważyć, że jest ono w naszej kulturze najczęściej zakorzenione w chrześcijaństwie. $Z$ tego punktu widzenia mocno akcentuje się, iż człowiek składa się z ciała i psychiki, która z jednej strony jest funkcją ciała, z drugiej zaś stanowi duszę i ducha. Relacja duch - dusza jest dwukierunkowa ${ }^{23}$. "Nie da się oddzielić ciała od duszy oraz wymiaru duchowego, który jest dla człowieka bardziej podstawowy niż wymiar biologiczny”24, zauważa Krzysztof Leśniewski. Dopiero dopełnienie wymiaru duchowego wskazuje na pełne, wielostronne ujęcie zdrowia.

Zdrowie jest naszym stanem naturalnym. Dodajmy do tego samopoczucie duchowe - stan, w którym odczuwa się nieustanną radość i smak życia, ma się poczucie spełnienia i świadomość harmonii z otaczającym Wszechświatem. Jest to stan, w którym czujemy się wciąż młodzi, wciąż pogodni i wciąż szczęśliwi25

22 T. Parsons, Struktura społeczna a osobowość, Państwowe Wydawnictwo Ekonomiczne, Warszawa 1969, s. 329.

${ }^{23}$ R. Grzegorczykowa, Co o fenomenie duchowości mówi język?, [w:] Fenomen duchowości, red. A. Grzegorczyk, J. Sójka, R. Koschany, Wydawnictwo Naukowe Uniwersytetu im. Adama Mickiewicza w Poznaniu, Poznań 2006.

${ }^{24}$ K. Leśniewski, "Nie potrzebują lekarza zdrowi..." Hezychastyczna metoda uzdrawiania człowieka, Wydawnictwo KUL, Lublin 2006, s. 9.

${ }^{25}$ D. Chopra, Twórzmy zdrowie, Wydawnictwo Naukowe PWN, Warszawa 1994, s. 11. 


\section{Dopiero poprzez swoją duchowość}

człowiek potrafi zająć świadomą i odpowiedzialną postawę wobec samego siebie, drugiego człowieka, świata oraz Boga. Człowiek dojrzały duchowo ma bowiem szansę dojrzale przeżywać siebie i kontakt z innymi ludźmi, dojrzale kształtować więzi i wartości oraz postępować w odpowiedni sposób ${ }^{26}$.

Punktem wyjścia w określaniu zdrowia duchowego jest zrozumienie samego siebie. Jego przejawem jest realizacja przykazania miłości, troska o prawdę, naukę o zdrowiu rozpatrywaną z punktu widzenia norm i zasad uznawanych przez kościoły chrześcijańskie ${ }^{27}$. Inaczej do zdrowia duchowego odnosi się psychologia.

W psychologii zdrowia kształtuje się tendencja do traktowania duchowości, jak właściwości (atrybutu) człowieka, bez przyjmowania założeń dotyczących istnienia czynników nadprzyrodzonych stanowiących jej źródło. Duchowość jako pojęcie psychologiczne ma status wielowymiarowego kontekstu teoretycznego ${ }^{28}$.

Współczesny człowiek coraz bardziej zainteresowany jest poszukiwaniem duchowości, troski o nią bowiem w sposób znaczący oddziałuje na zdrowie człowieka. Wsparcie duchowe dla wielu jest nie tylko ważnym elementem leczenia, ale samego życia, stanowiąc energię sprzyjającą rozwiązywaniu konfliktów i problemów ${ }^{29}$. Współczesna medycyna nie dysponuje lekami gwarantującymi uzdrowienie całego człowieka. Nie istnieją środki farmaceutyczne

${ }^{26}$ M. Madej-Babula, G. Noszczyk, Zdrowie i jego postrzeganie jako znaczacy wymiar ludzkiej duchowości, [w:] Edukacyjne przestrzenie zdrowia, red. Z. Marek, M. MadejBabula, Wydawnictwo WAM, Kraków 2009, s. 181.

27 Ibidem, s. 183-184.

${ }^{28}$ I. Heszen, H. Sęk, Psychologia zdrowia, Wydawnictwo naukowe PWN, Warszawa 2007, s. 72.

${ }^{29}$ A. Molesztak, Duchowy wymiar zdrowia człowieka, [w:] Konteksty zdrowia i edukacji zdrowotnej, op cit. 
leczące sferę duchową. Świadomość tych ograniczeń skłania ludzi do poszukiwania pomocy wśród mistrzów duchowych ${ }^{30}$.

Holistyczne ujęcie zdrowia to perspektywa wskazanych czterech wymiarów, nieredukująca człowieka do bytu psycho-fizjologicznego, ale wskazująca wyraźnie na pierwiastek duchowy w człowieku. Wzbogacenie definicji zdrowia o wymiar duchowy jest istotne dla prowadzenia badań interdyscyplinarnych uwzględniających zarówno współczesną wiedzę medyczną, jak i filozoficzną czy teologiczną. Takie postrzeganie zdrowia przyczynia się nie tylko do rozwoju medycyny humanistycznej, ale również do zmiany podejścia w leczeniu chorego człowieka uwzględniającego autonomię i podmiotowość oraz niepowtarzalność i sens każdego życia.

Zdrowie należałoby zestawić ze sprawnością organizmu (tak wynika z wielu przytoczonych wyżej definicji). Czy jednak można te terminy traktować jako synonimy? Czy sprawność fizyczna, psychiczna, psychomotoryczna, percepcyjna, umysłowa jest równoznaczna z byciem zdrowym? Wydawać mogłoby się, że tak jest, jednak nie zawsze. Niepełnosprawność - sprawność to pewne kontinuum, na którym można ulokować stan sprawności człowieka w różnych obszarach jego życia. Człowiek ten może doświadczać zdrowia bądź jego braku. Analizując związek zdrowia z niepełnosprawnością, należy zauważyć, że zdrowie $\mathrm{w}$ wielu wymienionych wymiarach przysługuje osobom z niepełnosprawnością. Niesprawność (trwała lub okresowa) pewnych narządów w organizmie nie odbiera możliwości odczuwania przez osobę niepełnosprawną zdrowia fizycznego, psychicznego czy duchowego. Istnieje wiele przykładów osób z niepełnosprawnością, które - mimo swoich, np. fizycznych czy percepcyjnych ograniczen - doświadczają pełni życia $^{31}$. Weiss ${ }^{32}$ twierdził, że człowiek jest zdrowy, kiedy powraca do

${ }^{30}$ K. Leśniewski, op. cit., s. 10.

31 Przykładem są chociażby niepełnosprawni sportowcy lub osoby takie, jak: Joni Eareckson Tada autorka książki Nowa Joni, Wydawnictwo: Fundacja „Bez barier”, Warszawa 1999; Nick Vujicik autor książki Bez rąk, bez nóg, bez ograniczeń!, Wydawnictwo Aetos Media, Wrocław 2012; głuchoniewidomy Peter Hepp autor 
społecznego życia. Może z powodu niepełnosprawności człowiek nie może wykonywać wielu rzeczy, w taki sam sposób jak robi to człowiek w pełni sprawny, ale nie oznacza to, że nie można ich wykonać inaczej i osiągnąć zaplanowany cel.

\section{Pojęcie choroby}

"Złe zdrowie, czyli choroba"33 jest kolejnym rozpoczynającym wiele dyskursów pojęciem. Płynność i wieloznaczność definicji tegoż pojęcia jest imponująca34.Jedne są bardzo ogólne i koncentrują się wyłącznie na aspekcie organicznym, a inne wprost przeciwnie, sięgają szerzej, wykraczając poza medyczne jej widzenie.

Słusznie podkreślają Julian Aleksandrowicz, Stefan Leder, Anna Pohorecka ${ }^{35}$, iż analiza pojęcia choroby w różnych jej aspektach zaciera granicę pomiędzy zdrowiem a chorobą. Autorzy zauważają, że „za stan chorobowy uznaje się taką sytuację, w której coś uniemożliwia normalne, zróżnicowane funkcjonowanie społeczne". Choć, jak piszą dalej, organizm funkcjonuje nadal, jednak w sposób inny niż organizm "zdrowy”. „Reakcje biologiczne i przeżycia psychiczne są wówczas specyficzne, zmienia się sposób odczuwania i przeżywania - człowiek staje się wielokrotnie bardziej wrażliwy na pewne rodzaje bodźców, zarówno fizycznych, jak i psychicznych"36. Inny pogląd wyraża Barbara Uramowska-Żyto ${ }^{37}$, podkreślając, że

książki Świat w moich dłoniach. Życie bez stuchu $i$ wzroku, Wydawnictwo Credo, Poznań 2002.

32 Za: C. Łuszczyński, O łagodzeniu skutków kalectwa, Instytut Wydawniczy CRZZ, Warszawa 1980.

33 M. Sokołowska, Granice medycyny, Wiedza Powszechna, Warszawa 1980, s. 11.

34 P. Zaborowski, Filozofia postepowania lekarskiego, PZWL, Warszawa 1990, s. 42.

35 J. Aleksandrowicz, S. Leder, A. Pohorecka A., O chorobie inaczej, PZWL, Warszawa 1977.

36 Ibidem, s. 51.

${ }_{37}$ B. Uramowska-Żyto, Medycyna jako wiedza i system działań, Analiza socjologiczna, Polska Akademia Nauk. Instytut Filozofii i Socjologii, Wydawnictwo - Zakład Narodowy Ossolińskich, Wrocław 1980. 
zdrowie i choroba zajmują przeciwstawne bieguny i są pojęciami wyraźnie odgraniczonymi. Analiza wielu definicji wskazuje, że żadna z nich nie zawiera zgodnych kryteriów, które określałyby, w którym momencie można mówić o chorobie. Zapewne ich ustalenie w wymiarze medycznym staje się nieco łatwiejsze. Emil Cioran, definiując pojęcie choroby, podaje prowokacyjne jej ujęcie:

Ciało, które się emancypuje, buntuje i nie chce więcej służyć - tym jest choroba, apostazja organów. Każdy z nich pragnie pohasać na własną rękę; każdy w sposób nagły lub stopniowy odmawia udziału w grze, współpracy z innymi, i rzuca się w przygodę i kaprys ${ }^{38}$.

\section{I dalej}

O ile w zdrowiu organy są dyskretne, to podczas choroby stają się niecierpliwe, chcą, by je zauważono, więc zaczynają z sobą konkurować, współzawodniczyć o naszą uwagę ${ }^{39}$.

Choroba, tak jak zdrowie, „nie jest czymś wyodrębnionym w organizmie", lecz jest czymś, co dotyczy całej osoby i wszystkich wymiarów jej życia ${ }^{40}$. Coraz wyraźniejsza staje się potrzeba uwzględniania jakości zdrowia i koncentracji wysiłków na "czującym bycie ludzkim” niż na samej chorobie ${ }^{41}$. Ten aspekt podnosi także Fritjof Capra ${ }^{42}$, opierając się na systemowej teorii zdrowia, według której choroba jest w swej istocie zjawiskiem umysłowym. Proces choroby można w wielu wypadkach odwrócić, łącząc metody terapii fizycznej i psychicznej. Zarys pojęciowy takiej metody musi uwzględniać ludzkie przeżycia i zachowania, rozumienie

38 E. Cioran, O chorobie, „Sztuka leczenia” 1995, tom 1, nr 2, s. 7.

39 Ibidem, s. 8.

${ }^{40}$ W. Budziński, Koncepcje i kryteria zdrowia, [w:] Rozwój poprzez terapię. Interdyscyplinarne aspekty pedagogiki leczniczej, red. M. Bidzian, W. Budziński, Wydawnictwo Gdańskiej Wyższej Szkoły Humanistycznej, Gdańsk 2011, s. 28.

${ }^{41} \mathrm{H}$. Wardaszko-Łykowska, Wprowadzenie do zagadnień psychologii w praktyce lekarskiej [w:] Psychologia w praktyce lekarskiej, op. cit, s. 21.

42 F. Capra, Punkt zwrotny. Nauka, społeczeństwo, nowa kultura, Państwowy Instytut Wydawniczy, Warszawa 1987. 
organizmu człowieka jako systemu dynamicznego, obejmującego zależne od siebie prawidłowości fizjologiczne i psychologiczne, oraz szerszy kontekst systemów - fizycznych, społecznych i kulturowych - w jakich żyje człowiek ${ }^{43}$. Stąd tak istotny i w przypadku choroby staje się wspomniany wymiar duchowy.

I znowu powstaje pytanie: czy chorobę można w prosty sposób zestawić i utożsamiać z niepełnosprawnością? Światowa Organizacja Zdrowia przedstawia trójwymiarowość niepełnosprawności, która jest wyrazem nowego spojrzenia na zjawisko. Wprowadza ona trzy terminy: uszkodzenie, niepełnosprawność i upośledzenie ${ }^{44}$.

Uszkodzenie - wszelka strata lub wada psychiczna, fizjologiczna lub anatomiczna w strukturze albo czynności. Może być ono okresowe lub trwałe, wrodzone lub nabyte oraz częściowe lub całkowite.

Niepełnosprawność - to ograniczenie lub brak wynikający z uszkodzenia zdolności do wykonywania czynności w sposób lub w zakresie przyjętym za normalny dla człowieka. Niepełnosprawność może być jednozakresowa (sfera sensoryczna, psychiczna, fizyczna) lub wielozakresowa (obejmować kilka zakresów równocześnie, choć ich stopień może być różny).

Upośledzenie - niekorzystna sytuacja danej osoby wynikająca z uszkodzenia lub niepełnosprawności polegająca na ograniczeniu lub całkowitym uniemożliwieniu wypełnienia ról społecznych i zadań życiowych zgodnych z normami (prawnymi i społecznymi).

Zestawienie wcześniejszych rozważań na temat choroby i powyższych terminów dotyczących ogólnie pojętej niepełnosprawności, wskazuje na pewne podobieństwa: zarówno choroba, jak i niepełnosprawność są pewnym odchyleniem od stanu typowego dla człowieka zdrowego/pełnosprawnego, obie doświadczane sytuacje powodują określone ograniczenia w funkcjonowaniu oraz obie mogą powodować pewne skutki w społecznym funkcjonowaniu osoby. Jednak różnice między nimi są nadal znaczne, co przedstawiono w tabeli 1.

\footnotetext{
43 Ibidem.

${ }^{44}$ C. Kosakowski, op. cit.
} 
Tabela. 1. Choroba a niepełnosprawność - różnice

\begin{tabular}{|c|c|}
\hline $\begin{array}{l}\text { Choroba (z wyłączeniem } \\
\text { chorób przewlekłych) }\end{array}$ & Niepełnosprawność \\
\hline $\begin{array}{l}\text { Określony czas trwania, wahania w obrę- } \\
\text { bie jednej jednostki chorobowej (okre- } \\
\text { ślone fazy choroby) }\end{array}$ & $\begin{array}{l}\text { Stan względnie trwały (czasem nieod- } \\
\text { wracalny) }\end{array}$ \\
\hline $\begin{array}{l}\text { W wielu przypadkach istnieją środki } \\
\text { farmakologiczne usuwające chorobę }\end{array}$ & $\begin{array}{l}\text { Nie ma środków farmakologicznych usu- } \\
\text { wających niepełnosprawność (mogą być } \\
\text { jedynie takie, które wspomagają funkcjo- } \\
\text { nowanie człowieka) }\end{array}$ \\
\hline \multicolumn{2}{|l|}{ Działania głównie rehabilitacyjne } \\
\hline $\begin{array}{l}\text { Może pojawiać się wielokrotnie w cią- } \\
\text { gu życia jednego człowieka }\end{array}$ & $\begin{array}{l}\text { Ta sama niepełnosprawność trwa względ- } \\
\text { nie niezmiennie (ewentualnie istnieje moż- } \\
\text { liwość pogłębienia się jej lub łagodzenia } \\
\text { skutków poprzez oddziaływania rehabili- } \\
\text { tacyjne, fizjoterapeutyczne itp., pojawienia } \\
\text { się innej, dodatkowej niepełnosprawności) }\end{array}$ \\
\hline $\begin{array}{l}\text { Może być zakaźna, czyli przenoszona } \\
\text { z jednego człowieka na drugiego }\end{array}$ & Nie jest stanem zakaźnym \\
\hline $\begin{array}{l}\text { Nie wymaga długotrwałego kontaktu } \\
\text { z instytucją medyczną (lekarzem, reha- } \\
\text { bilitantem, służbą zdrowia) }\end{array}$ & $\begin{array}{l}\text { Kontakt ze służą zdrowia w wielu przy- } \\
\text { padkach pozostaje długotrwały (raczej } \\
\text { stała opieka lekarza, rehabilitanta) }\end{array}$ \\
\hline
\end{tabular}

Źródło: opracowanie własne

Choroba przewlekła zasługuje na osobne potraktowanie, gdyż jej specyfika jest zupełnie inna niż choroby ostrej, a i ona sama znacznie częściej przeplata się z niepełnosprawnością (bywa, że ich zakresy znaczeniowe pokrywają się częściowo lub nawet całkowicie, sama choroba przewlekła może być przyczyną niepełnosprawności lub może - choć nie musi - do niepełnosprawności prowadzić).

\section{Pojęcie choroby przewlekłej}

Istotnym pojęciem w prezentowanych rozważaniach jest pojęcie choroby przewlekłej, niekiedy zamiennie określanej jako chroniczna, która stanowi coraz bardziej znaczący problem w lecznictwie. 
Nie obchodzi się ono bez trudności. Jest ono wysoce nieostre i przez to trudne do precyzyjnego określenia ${ }^{45}$. I tu także, pomimo wielu analiz, nie podano jednej obowiązującej definicji. Analizy różnicujące podejścia dotyczą czasu trwania choroby przewlekłej, jej objawów czy też skutków, jakie powoduje.

Mała encyklopedia medycyny wyjaśnia:

chroniczny, przewlekły, czynnik lub choroba o długotrwałym przebiegu i najczęściej słabym nasileniu objawów. Np. przez choroby chroniczne rozumiemy choroby trwające miesiącami lub latami, przebiegające zwykle $\mathrm{z}$ mało gwałtownymi, niezbyt nasilonymi objawami. Przeciwieństwem choroby przewlekłej jest choroba ostra - występująca nagle, o burzliwym przebiegu, nasilonych objawach i trwająca od kilku godzin do kilkunastu tygodni ${ }^{46}$.

Komisja ds. Chorób Przewlekłych (Commission on Chronic Illness) określa choroby przewlekłe jako

te wszystkie upośledzenia albo odchylenia od normy [stanu zdrowia M.S], które wykazują jedną lub kilka z następujących cech: są trwałe, pozostawiają rezydualną niepełnosprawność, spowodowane są przez nieodwracalne zmiany patologiczne, wymagają szczególnego szkolenia pacjenta $\mathrm{w}$ zakresie rehabilitacji, [a także - M.S.] oczekiwać można, że wymagać będą długotrwałego profesjonalnego nadzoru, obserwacji lub opieki ${ }^{47}$.

Definicja WHO z 2002 r. odmiennie formułuje pojęcie choroby przewlekłej, wskazując, że wymagają one „ciągłej opieki trwającej na przestrzeni lat lub dekad"48. Jak widać, definicja ta wskazuje tylko dwie cechy omawianej grupy chorób. Są nimi: trwanie choroby w czasie oraz generowane przez chorobę działania opiekuńcze.

${ }^{45}$ M. Skrzypek, Perspektywa chorego w socjologii choroby przewlektej, Wydawnictwo KUL, Lublin 2011, s. 112.

${ }^{46}$ Mała encyklopedia medycyny, tom I, Państwowe Wydawnictwo Naukowe, Warszawa 1982, s. 165.

${ }^{47}$ Za: M. Skrzypek, op. cit., s. 110-111.

48 Ibidem, s. 113. 
Choroby przewlekłe, będąc zjawiskiem odmiennym, łączy kilka wspólnych właściwości. Są to: długi czas trwania (od kilkunastu tygodni wzwyż); łagodniejszy niż w stanie ostrym przebieg; na ogół także nieodwracalność zaistniałych zmian patologicznych; konieczność stałego leczenia. Zatem sytuacja osoby z chorobą przewlekłą uzależniona w znacznej mierze od ciężkości choroby (stopnia wyłączenia z normalnego życia) oraz czasu trwania choroby ${ }^{49}$.

Kazimierz Jankowski ${ }^{50}$ zauważa, że pojęcie choroby przewlekłej jest niejako powiązane z pojęciem „inwalidztwa”. „Pojęcia te, jak wiadomo, nie są całkowicie jednoznaczne, ani też wyraźnie od siebie odgraniczone. Podkreślają one różne aspekty tego samego, w zasadzie zjawiska." Mówiąc o chorobie, mamy na uwadze pewien proces, podczas gdy niepełnosprawność jest raczej pewnym, względnie stałym, stanem ${ }^{51}$.

\section{Zachowanie wobec choroby/niepełnosprawności}

Ludzie chorzy czy niepełnosprawni postrzegają swoją sytuację w różny sposób, co przekłada się na zróżnicowane ich zachowania. Wspominana wcześniej Grażyna Dolińska-Zygmunt 52 zwraca uwagę, że czasem choroba wywołuje wiele zmian w życiu danej osoby i wówczas otoczenie spostrzega ją jako inną - odmienioną w swym zachowaniu, a $\mathrm{z}$ kolei $\mathrm{u}$ innej osoby zmian nie dostrzega, nadal pozostaje ona taką, jak była przed chorobą, mimo że doświadcza bólu i wielu ograniczeń. Podobnie dzieje się $w$ przypadku niepełno-

${ }^{49}$ M.T. Nowakowska, Psychologiczne aspekty chorób przewlekłych, trwałego upośledzenia zdrowia oraz chorób nieuleczalnych i zagrażających życiu, [w:] Psychologia lekarska, red. M. Jarosz, PZWL, Warszawa 1983, s. 343.

${ }^{50}$ K. Jankowski, Człowiek $i$ choroba. Psychofizjologiczne problemy przewlekłej choroby, inwalidztwa i rehabilitacji, Państwowe Wydawnictwo naukowe, Warszawa 1975, s. 6.

51 Zob. Ibidem; R. Ossowski, Teoretyczne i praktyczne podstawy rehabilitacji, Wydawnictwo Uczelniane Wyższej Szkoły Pedagogicznej w Bydgoszczy, Bydgoszcz 1999.

52 G. Dolińska-Zygmunt, op. cit., s. 243. 
sprawności, która pojawia się na jakimś etapie życia człowieka. Istota problemu może wyrażać się w sposobie, w jaki człowiek rozumie swoją sytuację, czyli na ile jest ona dla niego życiowym kryzysem i katastrofą, a na ile wiąże się z pewnymi korzyściami ${ }^{53}$.

Zatem zachowania wobec własnej choroby czy niepełnosprawności warunkowane są wieloma czynnikami. Dokonując pewnego uproszczenia, można wskazać dwie grupy czynników. Do pierwszej należą uwarunkowania zewnętrzne - m.in. sytuacja człowieka, dostępność usług medycznych, nastawienie otoczenia do chorego itp. Z kolei druga to uwarunkowania wewnętrzne - szeroko rozumiane właściwości jednostki ${ }^{54}$. Ujmując zagadnienie nieco inaczej, można wyodrębnić czynniki składające się na aktualną sytuację (mogą one wpływać w sposób bezpośredni jako bodźce lub pośrednio poprzez procesy poznawcze i emocjonalne) oraz czynniki podmiotowe związane $\mathrm{z}$ osobowością człowieka ${ }^{55}$.

Choroba czy niepełnosprawność stawia przed człowiekiem określone zadanie. Może być ono rozpatrywane z perspektywy jego udziału w realizacji celów zdrowotnych, ale także jako zachowania obronne stanowiące ustosunkowanie się do zagrożenia. Można wyróżnić trzy główne kierunki zachowania się człowieka wobec celów zdrowotnych. Są nimi: kierunek prozdrowotny, antyzdrowotny i pozazdrowotny. Pierwszy występuje wówczas, kiedy człowiek podejmuje zachowania ochraniające zdrowie i unikające chorób, a jeśli one wystąpią - zachowania eliminujące lub zwalczające choroby i odzyskujące zdrowie. Z kolei drugi z wymienionych kierunków dotyczy zachowań prowadzących do pogorszenia zdrowia, który może być przymusowy bądź atrakcyjny dla człowieka (np. nałogi, uzależnienia). Mówimy tu o aktywności ukierunkowanej na zmianę, która jedynie funkcje instrumentalne. Ostatni z wymienionych kierunków powiązany jest z zachowaniami zaniedbującymi

${ }^{53}$ M. Górnik, Dynamika roszczeń $i$ doświadczania niesprawiedliwości wśród ludzi chorych somatycznie, Wydawnictwo Uniwersytetu Śląskiego, Katowice 1994, s. 15.

54 G. Dolińska-Zygmunt, op. cit., s. 243.

55 I. Heszen-Klemens, Psychologia medyczna. Główne kierunki badań, Uniwersytet Śląski, Katowice 1983. 
działania zmierzające do utrzymania zdrowia. Widoczniejsze jest to wówczas, kiedy po zachorowaniu człowiek kontynuuje swoje zachowania tak, jakby nic się nie stało. Postawa taka może być wynikiem reakcji zaprzeczenia chorobie lub gdy wymagania związane $\mathrm{z}$ rolą chorego uniemożliwiają wypełnianie innych ważnych ról zarówno społecznych, jak i rodzinnych czy zawodowych ${ }^{56}$.

\section{Zakończenie}

Paradoks myślenia człowieka zawiera się w sytuacji dotyczącej większej koncentracji na zjawisku, którego się on obawia i którego chciałby uniknąć - choroby czy niepełnosprawności. Mniej z kolei uwagi przykłada do stanu, którego oczekuje - zdrowia. Można by rzec, że nie docenia tego, co posiada i nie dąży do utrzymania tego stanu. Zdrowie jest przecież stanem, którego wszyscy sobie wzajemnie życzą chociażby z okazji urodzin, imienin, rocznicy ślubu itp. lub kończąc przypadkowe spotkanie. A zatem dbałość o zdrowie, sprawność oraz dbałość o jej jakość powinna zajmować większość naszych starań. To nie tylko efektywne leczenie choroby, ale przede wszystkim podejmowanie działań, które uchronią nas przed zaburzeniami zdrowia, chorobą czy niepełnosprawnością. Wymaga to wdrażania prawidłowych działań wychowawczych, opiekunczych, profilaktycznych, które zwiększą szanse na zdrowe życie ${ }^{57}$ czy nakierują działania na dbanie o jego jakość w sytuacji niepełnosprawności.

Mając kontakt z osobą chorą czy niepełnosprawną - jako bliscy (rodzina, przyjaciele) czy profesjonaliści, powinniśmy pamiętać, iż każdy inaczej choruje lub odbiera stan niepełnosprawności. Przypisuje im odmienny sens i znaczenie, przeżywa zróżnicowane

56 Ibidem, s. 95-96.

57 E. Kasperek-Golimowska, Choroba dziecka jako sytuacja trudna w życiu rodziny, [w:] Sytuacje trudne wżyciu dziecka, red. M. Cywińska, Wydawnictwo Uniwersytetu im. Adama Mickiewicza, Poznań 2008. 
stany psychiczne i emocjonalne, snuje rozmaite przypuszczenia i przewidywania 58 .

Próba formułowania zakresu pojęciowego zdrowia i choroby jak zauważa Adam Fijewski59 - służy uporządkowaniu pojęć zwłaszcza z perspektywy służby zdrowia, która aby poprawić swoje działania, powinna posiadać odpowiednią aparaturę pojęciową umożliwiającą jej kodyfikowanie procedur z zakresu różnych specjalności. Podobne znaczenie ma porządkowanie pojęć związanych $\mathrm{z}$ niepełnosprawnością. Ponadto myślenie o zdrowiu/sprawności jest niezbędne z punktu widzenia społeczno-kulturowej potrzeby doskonalenia lub samodoskonalenia się człowieka. Wreszcie - rozumienie pojęcia zdrowia i choroby, sprawności i niepełnosprawności ma kluczowe znaczenie dla wzajemnych relacji człowieka z ograniczeniem sprawności ze specjalistą czy też pacjenta z lekarzem $^{60}$. Przyjęcie określonego rozumienia generuje charakterystyczny sposób zawierania i utrzymywania różnorodnych relacji (lekarz - pacjent, rehabilitant - pacjent, podopieczny - pedagog specjalny itp.), a zatem i ich wzajemne prawa czy zobowiązania.

\section{Bibliografia:}

Aleksandrowicz J., Sumienie ekologiczne, Biblioteka Wiedzy Współczesnej OMEGA, Warszawa 1979;

Aleksandrowicz J., Leder, S., Pohorecka A., O chorobie inaczej, PZWL, Warszawa 1977.

Aleksandrowicz J., Nie ma nieuleczalnie chorych, Wydawnictwo Iskry, Warszawa 1982.

58 Za: S. Leder, Stres zawodowy pracowników medycznych, [w:] Psychiatryczne i psychologiczne aspekty praktyki medycznej. Wybrane zagadnienia psychiatrii konsultacyjnej/ Miaison, red. S. Leder, C. Brykczyńska, Biblioteka Psychiatrii Polskiej, Kraków 1999, s. 51 .

${ }^{59}$ A. Fijewski, Droga ku zdrowiu - kilka refleksji o ksztattowaniu zachowań i obyczaju, [w:] Wybrane zagadnienia z edukacji zdrowotnej, red. M. Juszczyk, Wydawnictwo Wyższej Szkoły Ekonomii i Prawa im. Prof. Edwarda Lipińskiego w Kielcach, Kielce 2010, s. 37.

60 Por. P. Zaborowski, op. cit., s. 23. 
Aleksandrowicz J., Stawowy E., Tyle wart jest człowiek..., Wydawnictwo Lubelskie, Lublin 1992.

Aleksandrowicz J., Sumienie ekologiczne, Biblioteka Wiedzy Współczesnej OMEGA, Warszawa 1979.

Budziński W., Koncepcje i kryteria zdrowia, [w:] Rozwój poprzez terapię. Interdyscyplinarne aspekty pedagogiki leczniczej, red. M. Bidzian, W. Budziński, Wydawnictwo Gdańskiej Wyższej Szkoły Humanistycznej, Gdańsk 2011.

Capra F., Punkt zwrotny. Nauka, społeczeństwo, nowa kultura, Państwowy Instytut Wydawniczy, Warszawa 1987.

Chojnacka-Szawłowska G., Rozpoznanie choroby nowotworowej. Uwarunkowania psychologiczne, PZWL, Warszawa 1998.

Chopra D., Twórzmy zdrowie, Wydawnictwo Naukowe PWN, Warszawa 1994.

Cioran E., O chorobie, „Sztuka leczenia” 1995, tom 1, nr 2.

Dolińska-Zygmunt G., Teoretyczne podstawy refleksji o zdrowiu, [w:] Podstawy psychologii zdrowia, red. G. Dolińska-Zygmunt, Wydawnictwo Uniwersytetu Wrocławskiego, Wrocław 2001.

Dubos R., Człowiek, środowisko, adaptacja, PZWL, Warszawa 1970.

Eareckson Tada J., Nowa Joni, Wydawnictwo: Fundacja „Bez barier”, Warszawa 1999.

Fijewski A., Droga ku zdrowiu - kilka refleksji o kształtowaniu zachowań i obyczaju, [w:] Wybrane zagadnienia z edukacji zdrowotnej, red. M. Juszczyk, Wydawnictwo Wyższej Szkoły Ekonomii i Prawa im. Prof. Edwarda Lipińskiego w Kielcach, Kielce 2010.

Górnik M., Dynamika roszczeń i doświadczania niesprawiedliwości wśród ludzi chorych somatycznie, Wydawnictwo Uniwersytetu Śląskiego, Katowice 1994.

Grzegorczykowa R., Co o fenomenie duchowości mówi język?, [w:] Fenomen duchowości, red. A. Grzegorczyk, J. Sójka, R. Koschany, Wydawnictwo Naukowe Uniwersytetu im. Adama Mickiewicza w Poznaniu, Poznań 2006.

Heszen I., Sęk H., Psychologia zdrowia, Wydawnictwo naukowe PWN, Warszawa 2007.

Heszen-Klemens I., Poznawcze uwarunkowania zachowania sie wobec wtasnej choroby, Zakład Narodowy Imienia Ossolińskich, Wydawnictwo Polskiej Akademii Nauk, Wrocław 1979.

Heszen-Klemens I., Psychologia medyczna. Główne kierunki badań, Uniwersytet Śląski, Katowice 1983.

Jankowski K., Człowiek i choroba. Psychofizjologiczne problemy przewlekłej choroby, inwalidztwa i rehabilitacji, PWN, Warszawa 1975.

Kasperek-Golimowska E., Choroba dziecka jako sytuacja trudna w życiu rodziny, [w:] Sytuacje trudne wżyciu dziecka, red. M. Cywińska, Wydawnictwo Uniwersytetu im. Adama Mickiewicza, Poznań 2008.

Kirschner H., Pojęcie zdrowia i jego ocena, [w:] Medycyna zapobiegawcza i środowiskowa. Higiena - ekologia kliniczna - zdrowie, red. Z. Jethona, PZWL, Warszawa 1997. 
Kondas O., Psychologia kliniczna, PWN, Warszawa 1984.

Kornas S., Nauczanie etyki czynnikiem integrujacym studia medyczne, [w:] Nauczanie etyki w uczelniach medycznych, red. J. Suchorzewska, M. Olejniczak, Akademia Medyczna w Gdańsku, Gdańsk 2007.

Kosakowski Cz., Węzłowe problemy pedagogiki specjalnej, Wydawnictwo Edukacyjne Akapit, Torun 2003.

Kościńska E., Biologiczne aspekty zdrowia, [w:] Konteksty zdrowia i edukacji zdrowotnej, red. M. Kuchcińska, E. Kościńska, Wydawnictwo Uniwersytet Kazimierza Wielkiego, Bydgoszcz 2010.

Leder S., Stres zawodowy pracowników medycznych, [w:] Psychiatryczne i psychologiczne aspekty praktyki medycznej. Wybrane zagadnienia psychiatrii konsultacyjnej/liaison, red. S. Leder, C. Brykczyńska, Biblioteka Psychiatrii Polskiej, Kraków 1999.

Leśniewski K., "Nie potrzebują lekarza zdrowi..." Hezychastyczna metoda uzdrawiania człowieka, Wydawnictwo KUL, Lublin 2006.

Lipowski Z.J., Physical Illness the indyvidual and the coping process, "Psychiat. Med." $1979,1$.

Łuszczyński C., O łagodzeniu skutków kalectwa, Instytut Wydawniczy CRZZ, Warszawa 1980.

Madej-Babula M., Noszczyk G., Zdrowie i jego postrzeganie jako znaczacy wymiar ludzkiej duchowości, [w:] Edukacyjne przestrzenie zdrowia, red. Z. Marek, M. Madej-Babula, Wyższa Szkoła Filozoficzno-Pedagogiczna „Ignatianum”, Wydawnictwo WAM, Kraków 2009.

Mała encyklopedia medycyny, tom I, PWN, Warszawa 1982.

Molesztak A., Duchowy wymiar zdrowia człowieka, [w:] Konteksty zdrowia i edukacji zdrowotnej, red. M. Kuchcińska, E. Kościńska, Wydawnictwo Uniwersytetu Kazimierza Wielkiego, Bydgoszcz 2010.

Nowakowska M.T., Psychologiczne aspekty chorób przewlektych, trwałego upośledzenia zdrowia oraz chorób nieuleczalnych i zagrażających życiu, [w:] Psychologia lekarska, red. M. Jarosz, PZWL, Warszawa 1983.

Obuchowska I., Krawczyński M., Chore dziecko, Nasza Księgarnia, Warszawa 1991.

Ossowski R., Teoretyczne i praktyczne podstawy rehabilitacji, Wydawnictwo Uczelniane Wyższej Szkoły Pedagogicznej w Bydgoszczy, Bydgoszcz 1999.

Parsons T., Struktura społeczna a osobowość, Państwowe Wydawnictwo Ekonomiczne, Warszawa 1969.

Hepp P., Świat w moich dłoniach. Życie bez stuchu $i$ wzroku, Wydawnictwo Credo, Poznań 2002.

Piątkowski W., Choroba jako zjawisko socjologiczne. Wprowadzenie do wybranych koncepcji badawczych, [w:] Zdrowie i choroba. Wybrane problemy socjologii medycyny, red. J. Barański, W. Piątkowski, Oficyna Wydawnicza ATUT, Wrocławskie Wydawnictwo Oświatowe, Wrocław 2002. 
Skrzypek M., Perspektywa chorego w socjologii choroby przewlekłej, Wydawnictwo KUL, Lublin 2011.

Sokołowska M., Granice medycyny, Wiedza Powszechna, Warszawa 1980.

Sontag S., Choroba jako metafora AIDS i jego metafory, PIW, Warszawa 1999.

Uramowska-Żyto B., Medycyna jako wiedza i system działań, Analiza socjologiczna, Polska Akademia Nauk. Instytut Filozofii i Socjologii, Wydawnictwo - Zakład Narodowy Ossolińskich, Wrocław 1980.

Uramowska-Żyto B., Zdrowie i choroba w świetle wybranych teorii socjologicznych, Instytut Filozofii i Socjologii PAN, Warszawa 1992.

Vujicik N., Bez rąk, bez nóg, bez ograniczeń!, Wydawnictwo Aetos Media, Wrocław 2012. Wardaszko-Łykowska H., Wprowadzenie do zagadnień psychologii w praktyce lekarskiej, [w:] Psychologia w praktyce lekarskiej, red. M.H. Hollender, Państwowy Zakład Wydawnictw lekarskich, Warszawa 1975.

Zaborowski P., Filozofia postępowania lekarskiego, PZWL, Warszawa 1990. 